\title{
Performative Rights and Situationist Ethics
}

\begin{abstract}
Recent critiques of rights have enabled alternative understandings of the role of rights in contemporary politics. In this article, I focus on the emergence of a performative understanding of rights, which conceptualises rights claims as reiterative acts that remake the protections and privileges marked out by rights. This promising reconstruction of rights requires a rethinking of the ethical justification of rights claims. If rights claims are creative political acts, rather than especially important duties, a justification focused on certainty and constraint will not do. Yet, we must still ask: what is a good rights claim? I argue, first, that a performative account of rights requires an ethical justification that embraces contingency while still providing an account of good political creativity, and, second, that focusing on the use of normative claims to address specific problems, which I term a situationist ethics - drawing on the philosophy of John Dewey, provides better grounding for performative rights claims.
\end{abstract}

Keywords: rights, performativity, ethics, pragmatism, democracy

\section{Performative Rights and Ethical Justification}

Rights are tools. They are rules directing how we live, articulating the socially sanctioned protections and privileges each of us possess. Rights can be legally enforced norms, culturally sanctioned moral imperatives, and rhetorical political claims contesting the existing order. This enumeration of the uses of rights, however, does not get at the ethical question, as the work we do with rights requires that we reflect on what justifies the protections and privileges granted. Thus, despite their contemporary ubiquity, there remains considerable disagreement over the value and proper function of 
rights. We always return to the question of how we know which rights are truly good rights, rather than de facto rules, contingent social norms, or self-regarding political manoeuvring. The work of knowing what our "real" rights are is a familiar philosophic vocation. Therefore, rather than rehearse established contests between rival theories, here I focus on an emerging alternative account of rights as performative claims. A performative account rejects the idea that rights are objectively grounded in essential human qualities (such as dignity, autonomy, or need) or the demands of reason (transcendental, communicative, or public). This rejection arises from both a widely-held scepticism of foundationalism, as well as an appreciation of the ambiguous consequences of proliferating rights claims. A performative account suggests rights are tools of political creativity that can justify both change and stability, which challenges our understanding of the political function of rights and thus requires a different ethical justification.

Where rights are thought to be trumps that protect individuals from the excesses of the popular will and scrum of political contestation, their justification is a matter of obligation, in which transcendent duty limits the freedom of our actions. ${ }^{1}$ Where rights are thought to provide a standard of legitimacy, their justification is tied to regulation, in which necessary principles constrain our action by limiting the diversity of our ends. ${ }^{2}$ In both instances we have an ethical justification that binds us to an authority demanding the sacrifice of a portion of our freedom to secure a higher good. This mode of ethical justification, concerned with certainty and constraint, is necessitated by understanding rights as a tool for erecting legitimate barriers between individuals and

\footnotetext{
${ }^{1}$ Karen Zivi, Making Rights Claims: A Practice of Democratic Citizenship (Oxford: Oxford University Press, 2012), 28-36.

${ }^{2}$ Linda M. G. Zerilli, "Value Pluralism and the Problem of Judgment Farewell to Public Reason," Political Theory 40, no. 1 (February 1, 2012): 7-8.
} 
communities. ${ }^{3}$ Rights on this model offer us protection from the unrestrained freedoms of others. As such, they tend to be linked to the rule of law and preservation of order rather than democratic activism. If, however, rights are seen as a tool of political creativity, with the potential to challenge the order of things, then they cannot be justified by an ethics of certainty and constraint.

It is the tension between creativity and control that inspired Hannah Arendt to suggest that morality and freedom were incompatible, ${ }^{4}$ and which presents the most pressing problem for a performative account of rights. The priority a performative understanding of rights gives to creativity and contingency contradicts dominant tendencies to establish normative principles in the abstract, such that general rules direct our actions as they are applied to specific situations. ${ }^{5}$ Thus, a performative account of rights must find its justification elsewhere. The ethical value of performative rights claims instead rests upon a judgement of the new worlds they enable us to make. This insight is shared across different performative accounts, yet as I will argue, the standards for what makes for good political creativity are thus far insufficient. My aim is to carry forward this development by providing a clearer articulation of the problem and a more robust justification for performative rights claims.

Rights, like all social norms, are constructive. They shape our subjectivity by articulating how we should act while delimiting our frames of recognition and response. In particular, rights provide a set of rules to guide our social interactions, specifying our political relationships: to ourselves, to others, and within the institutional order. Further, rights connect these rules and relationships to specific identities — such as civic

\footnotetext{
${ }^{3}$ Joe Hoover, Reconstructing Human Rights: A Pragmatist and Pluralist Inquiry into Global Ethics (Oxford: Oxford University Press, 2016), 26-33.

${ }^{4}$ Hannah Arendt, "Some Questions of Moral Philosophy," Social Research 61, no. 4 (Winter 1994): 739-64.

${ }^{5}$ This tendency is not limited to traditions seeking ethical grounding in the abstract and rational, as traditions that appeal to custom and virtue still tend to privilege the general over the specific.
} 
membership, national belonging, or universal humanity-which further interpolate individuals as rights holders. This suggests that we find ourselves in, and in fact are made ourselves by, a world of pre-made rights that we have neither authored nor given our assent. Conventional theories of rights do not make much of this, as justified rights rest on a general account of what is essentially valuable in our humanity or necessary to reason itself, such that the impediment of this pre-existing world of rights on our individual freedom is morally justified. For a performative account, our estrangement from the rights that shape and constrain us is of great concern as it is unclear what would justify that imposition.

As Wendy Brown argues, rights have the potential to disempower us. ${ }^{6}$ Brown argues that a politics focused on rights interpolates us as vulnerable subjects wounded by, but also dependent upon, the power of the state. This subjectivity is defined by its attachment to state institutions that deprive us of freedom, leading us to see ourselves as needy individuals rather than part of a collective political body, and thus undermining the possibility of a more democratic and active political subjectivity. Focusing on rights as creative claims, however, reveals a conspiratorial rights-politics, to borrow Bonnie Honig's characterisation, ${ }^{7}$ which exceeds Brown's juridical rights-politics. Brown sees rights as claims sanctioned by powerful actors and institutions, to which individuals can appeal but not fundamentally contest or transform. A conspiratorial politics makes more of the ambiguity of rights, as not all claims inculcate dependent political subjectivities. New rights claims can directly challenge established juridical

\footnotetext{
${ }^{6}$ Wendy Brown, States of Injury: Power and Freedom in Late Modernity (Princeton, NJ: Princeton University Press, 1995), 96-134.

${ }^{7}$ Bonnie Honig, Antigone, Interrupted (Cambridge University Press, 2013), 193-195. Also, see Honig, Emergency Politics: Paradox, Law, Democracy (Princeton, NJ: Princeton University Press, 2009), 6586.
} 
rights, and even institutionalised rights can be subverted to serve new purposes through political action.

Rights claims are always imperfectly reiterated and one of the key insights of a performative account of rights is that through political action we can make use of the ambiguity introduced by reiteration to turn rights toward more democratic ends. ${ }^{8}$ Drawing on Judith Butler's account of performativity, the subjectivity that a particular social regime articulates is not based on a singular ideological account of the individual, rather it is a kind of social script without an author, a script realised through multiple performances by diverse individuals, each performance a copy of a copy. While social structures and norms shape us in ways that undermine any account of subjectivity rooted in an ideal of rational individual autonomy, they do not instantiate a hegemonic socially determined subjectivity. Karen Zivi uses this insight to develop an account of rights as political performances that intentionally contest the existing construction of identity and norms, which do not only dispossess us of our freedom and independence, as they are open to being creatively reconstructed. This allows established identities and norms to potentially serve as a medium for changing political subjectivities through collective action in revitalised democratic communities. ${ }^{9}$

Performativity, therefore, holds significant potential for rethinking rights, but realising this potential requires confronting a distinctive ethical challenge. Embracing performativity means rights will not find their justification in a prescriptive understanding of ethics as abstract and universal rules; instead we must assess rights claims as creative claims made within specific contexts, focusing on the ethical value of what we make of ourselves through rights claims. In discussions of performative rights claims

\footnotetext{
${ }^{8}$ Karen Zivi, "Rights and the Politics of Performativity," in Judith Butler's Precarious Politics: Critical Encounters, ed. Terrell Carver and Samuel A. Chambers (London and New York: Routledge, 2008), 157-69.

${ }_{9}^{9}$ Zivi, Making Rights Claims, 81.
} 
thus far, however, the act of valuation has been underemphasised, in particular why we affirm particular goods when we engage in rights claiming and how we expect others to respond to those claims. The justification for a performative account is improved by focusing on the distinctly ethical valuations inherent in rights claims. Existing performative justifications prescribe an open-ended responsibility to a generalised "other" and an existential commitment to democracy, yet the affirmation of these ends rests on an unarticulated act of ethical valuation in which these ends are affirmed for reasons beyond personal commitment or aesthetic preference. Drawing from the work of John Dewey, I develop a situationist ethics that provides a clearer measure of the value of rights claims as acts of political creativity without reasserting the authority of general and abstract values of conventional ethical justification. ${ }^{10}$

Zivi argues rights claims are rhetorical claims made in the practice of democratic politics, which are inspired by our experiences of injustice but balanced against our need to give consideration to the broader social interest. ${ }^{11}$ This argument resonates with Butler's ethical justification for her performative account of politics, in which she links a performative account of subjectivity with Michel Foucault's ethics of self-cultivation and Emmanuel Levinas' idea of responsibility to the Other. ${ }^{12}$ In what follows, I argue this approach renders the audience for our rights claims both too specific (the existing national political community) and too diffuse (the abstract Other). Focusing on responsiveness is vital, as rights claims are fundamentally about how we relate to one another, therefore, any ethical justification of rights has to address the kinds of relationships these claims establish. A situationist ethics, however, provides an understanding

\footnotetext{
${ }^{10}$ A "situationist ethics" is distinct from "situational ethics", see Hoover, Reconstructing Human Rights, 103-136.

${ }^{11}$ Zivi, Making Rights Claims, 56-61.

12 Judith Butler, Giving an Account of Oneself (New York, NY: Fordham University Press, 2005), 340.
} 
of responsiveness that is more practical, while remaining sensitive to contingency. Rights claims address themselves to those who are affected by the problematic situations we are seeking to alter through our action, but this is done without presuming that the audience for rights claims will match up to any pre-existing notion of political community. Dewey's ethics are fundamentally concerned with creative practical action. '[S]hifting the issue to analysis of specific situations makes inquiry obligatory and alert observation of consequences imperative. No past decision nor old principle can ever be wholly relied upon to justify a course of action. ${ }^{, 13}$ This approach forces us to make explicit the way rights claims, like other ethical judgments, actively reconstruct our ethical community, altering the audience of our claims and at times calling a new audience into existence. Our judgments that a particular good is valuable as an ethical end entails a contingent and experimental demand for consideration from those to whom it is addressed, in turn in entails an obligation that such demands are based on a reciprocal care for others. In a situationist ethics these demands and obligations arise out of concrete experiences of injustice, as they inform creative interaction between individuals and communities in specific situations.

Linda Zerilli, drawing on Arendt's idea of political judgment, suggests that rights claims are not moral claims, but rather they are akin to aesthetic judgments that can only be understood subjectively. ${ }^{14}$ This move places the value of rights claims in their capacity to express our freedom in a manner that is communicable to others. We judge rights claims, then, based on what they make of us as members of a political community. Yet, aesthetic judgments still rest on some ethical valuation. In response, I argue that even as rights claims are expressive and aesthetic, they are still made with

\footnotetext{
13 John Dewey, Reconstruction in Philosophy (Mineola, NY: Dover Publications, 2004), 100.

${ }^{14}$ Linda M. G. Zerilli, "'We Feel Our Freedom' Imagination and Judgment in the Thought of Hannah Arendt," Political Theory 33, no. 2 (April 1, 2005): 158-88.
} 
some end-in-view. Zerilli accepts this to a degree, as the ends we pursue politically must be shareable, but I go further to suggest rights claims are not simply expressions of our individual commitments and aesthetic preferences, they are judgments made in favour of specific goods we pursue in response to concrete injustices. Therefore, the goods we pursue are subject to a more robust evaluation than Zerilli acknowledges because they are instrumental in a way her Arendtian framing rejects. Dewey criticises the dichotomy between instrumental and intrinsic value as an artefact of a class-based hierarchy separating practical activity from idealised values - in Arendt's case, freedom. Such a separation follows 'naturally from a failure to recognise that all knowing, judgment, belief represent an acquired result of the working of natural impulses in connection with environment. ${ }^{, 15}$ Freedom, therefore, finds its value in what in contributes to lived experience, both to the practical activity of daily life and as a guiding ideal.

Honig anticipates some of this in her account of emergent rights, focusing on how rights claims must be supplemented by a democratic ethos. ${ }^{16}$ She argues rights claims find their ethical justification as they express virtues associated with democratic activism, keeping alive the moment of democratic founding as an always-ongoing activity. For Honig, however, the pursuit of an ethical justification threatens to neutralise political contestation and naturalise the good that motivates our actions. Her solution is an agonistic humanism that tries to hold 'seemingly impossible simultaneous commitments ${ }^{17}$ in order to keep the democratic promise of rights claiming alive. This solution holds on to a flawed account of ethics that generates the very problem that Honig is trying to solve. If we follow Dewey, in place of the worry that the goods we affirm in our ethical judgments will conflict with the contingency of the world, we can conceive

\footnotetext{
15 John Dewey, Human Nature and Conduct: An Introduction to Social Psychology (Amherst, NY: Prometheus Books, 2002), 187.

${ }^{16}$ Honig, Emergency Politics, 40-64.

${ }^{17}$ Honig, Antigone, Interrupted, 193.
} 
of ethical judgment as the development and ongoing exercise of a creative critical intelligence that helps us cope with contingency. Dewey's ethics does this by focusing on how ethical commitments are constantly challenged in experience and renewed through reflective practice, as we pursue an always contingent and fallible notion of the good. As he asserted in Reconstruction in Philosophy, 'growth itself is the moral "end." 18

Accounts of performative rights have thus far focused more on their capacity to advance democratic political projects, leaving the ethical judgment that sits behind that only partly examined. By reconstructing the relationship between ethical and political judgment, it is possible to draw out the underlying ethical commitments in performative accounts of rights with greater clarity. In addition, the situationist ethics developed here provides a stronger justification for those commitments and a more practical articulation of their consequences. In the following sections I critique existing performative accounts of rights, revealing how they alter the question of ethical justification and generate distinctive difficulties. After this sympathetic diagnostic work, I return to Dewey's situationist ethics as a better justification of a performative account of rights.

\section{Desire, Responsibility, and Performative Politics}

In Undoing Gender, Butler considers how human rights claims can be potentially emancipatory by enabling the creation of new political worlds. ${ }^{19}$ She examines claims by LGBTI activists that redefine the frame of reference for humanity by performing alternative ways of being human and, thus, ask us to 'embrace the destruction and

\footnotetext{
${ }^{18}$ Dewey, Reconstruction in Philosophy, 102.

${ }^{19}$ Judith Butler, Undoing Gender (New York \& London: Routledge, 2004), 31-36.
} 
rearticulation of the human in the name of a more capacious and, finally, less violent world'. ${ }^{20}$ As Zivi elaborates,

to juxtapose gays and lesbians to humans and to demand that the former be included in the latter group is to simultaneously expose the category "human" as something other than universal and to make a claim for inclusion into a category — personhood - that gives it new meaning. ${ }^{21}$

These rights claims demand new privileges and protections, while also remaking our relationships to ourselves, to each other, and to the social order. This can range from rather minimal claims for the recognition of non-heterosexual marriage rights to more profound claims that undermine the naturalness of heterosexual intimate relationships. The performative work of remaking rights, however, does not result in a more complete and legitimate rights regime, nor does it invoke a more complete idea of human equality and freedom. Rather, the result of a performative claim is only a further performance, rather than the fuller realisation of a universal ideal.

Our rights-claims are always ambiguous and contestable. Butler, however, worries rights have a tendency to remain within the juridical order. While she acknowledges their capacity to rearticulate important political identities, Butler is concerned rights cannot promote a transformative politics without profound resignification. ${ }^{22}$ Zivi, however, sees more potential in rights, suggesting they are a fundamental aspect of democratic practice. ${ }^{23}$ She describes a rights politics that exceeds the juridical and is performed beyond the institutional spaces of governance. Rights claims are part of a rhetorical practice of persuasion, whereby we consciously and intentionally reconstitute

\footnotetext{
${ }^{20}$ Ibid., 35.

${ }^{21}$ Zivi, Making Rights Claims, 81.

${ }^{22}$ Butler, Undoing Gender, 223-227.

${ }^{23}$ Zivi, Making Rights Claims, 7-9.
} 
common meanings. ${ }^{24}$ This suggests the practice of rights claiming leaves space for the self-reflective reconstruction of our common world. Zivi conceptualises the politics of rights more broadly, so we can 'recognize that the very meaning and power of the rights claims are agreed upon and given reality by communities of individuals' and it is this process of political engagement beyond the juridical in which rights have greater democratic potential. ${ }^{25}$ Zivi undermines the criticism of rights as excessively juridical, showing how rights claims generate new relationships of recognition through democratic contestation. This helps addresses some of Butler's ambivalence while also highlighting the need for an ethical justification for such claim making. If a performative account of rights is more than a sociological theory of the practice of rights claiming, it must say something about which rights claims are best, or at least better.

Zivi asserts a performative account of rights cannot aspire to the same ethics of certainty as conventional accounts that limit their understanding of rights-claims to constative speech acts, in which we judge a claim based on its accuracy in relation to an existing principle. ${ }^{26}$ A performative account of rights aspires to another standard than felicity, which is whether a claim has illocutionary and perlocutionary force.$^{27}$ Further, Zivi suggests we read the force of a speech act in light of the fact that we will not be able to know or guarantee its success at the time of the act. Instead, we evaluate performative claims on whether they open up a new situation (does their illocutionary force do something?) and also what we make of that new situation (are we persuaded by their perlocutionary force?). ${ }^{28}$ With this shift in mind, we can see evaluating a performative

\footnotetext{
${ }^{24}$ Ibid., 117-119.

25 Ibid., 50.

${ }^{26}$ Ibid., 24.

${ }^{27}$ Ibid., $41 \& 45$.

${ }^{28}$ See Engin Isin, "Enacting International Citizenship," in International Political Sociology: Transversal Lines, ed. Tugba Basaran et al. (London and New York: Routledge, 2016), 186-189.
} 
rights claim will involve evaluating what a claim does, particularly what it does to open up new worlds and persuade others to share in those new worlds.

Zivi and Butler both appeal to the intertwining of individual desire and otherregarding responsibility to find an ethical ground for performative claims, drawing out how the illocutionary force of rights-claims can express desires for social change, while their perlocutionary force gives rise to a need to consider their consequences for others. Zivi argues rights claims express our desire for recompense after we have been injured. They also express our sense of justice, such that we are not simply demanding revenge but social recognition of our injury and public accountability. ${ }^{29}$ Rights claims, however, are not only appeals to have our demands met within the confines of the existing order, as they can demand that given understandings of justice must change. The force desire has in motivating rights claims is constrained by a need to take account of the interests of society as a whole. Therefore, rights claims must be other-regarding to be ethical. ${ }^{30}$ While this gives us some scope for distinguishing better from worse rights claims, Zivi's account raises a number of worries. First, the motivating feelings emphasised are hurt and anger, along with the desires to punish and seek revenge. These are a relatively limited set of motivators and she leaves unexamined whether hurts and injuries are the best motivators in democratic politics. Butler, for example, has shown how feelings of vulnerability and hurt were used to justify the US invasion of Iraq in 2003, an invasion that was also backed by claims that both the US and "international community had a right to respond to security threats. ${ }^{31} \mathrm{~A}$ focus on injury can stifle the openness required for democratic responsiveness, hindering our capacity to attend to those excluded from recognition within the current constellation of justice. This is related to a further issue

\footnotetext{
${ }^{29}$ Zivi, Making Rights Claims, 57-58.

${ }^{30}$ Ibid., 58.

${ }^{31}$ Judith Butler, Frames of War: When Is Life Grievable? (London and New York: Verso, 2009).
} 
with Zivi's account of the ethical quality of our rights claims, which is that their otherregarding quality is focused on those with whom we share membership in existing democratic polities. If we focus on established communities, then those outside that community are excluded from our practices of persuasion and risk being rendered invisible to us, suggesting rights are least useful for those who are most marginalised.

Butler expands on the ethical justification of performative claims, as her account is more open-ended about which desires motivate our claims and who we are responsible to in our claim-making. For Butler, performative claims express a desire to be differently while still being recognised by others within the social world. In Giving an Account of Oneself she draws on the work of Adorno to show that ethical questions emerge precisely when we do not know what to do, when our received social norms fail to guide us. ${ }^{32}$ This takes us beyond the hurt of injustice, which focuses on the failure of existing norms to be upheld fairly rather than on the diversity of desires that inspire political creativity. For Butler, the ethical moment leads us to experience the world of existing norms as a constraint on our behaviour and limit on our desires. It is as though the lack of a push in the moment of uncertainty reveals the pressure that was always exerted but to which we were previously insensible.

Butler's ethical moment provides a space to consider what she calls the question of liveability: how does one become oneself in a world shared with others, on whom we are necessarily dependent? She rejects Nietzsche's claim that the inculcation of a moral will is a kind of violence against the self, in which the power of social norms are internalised and used to repress the individual's will to power. ${ }^{33}$ Instead, she looks to how the ethical moment gives space for the expression of a multitude of creative desires

\footnotetext{
${ }^{32}$ Butler, Giving an Account of Oneself, 3-9.

${ }^{33}$ Ibid., 10-11.
} 
that exceed the given, linking this to Foucault's ethics of self-care, in which we remake ourselves in ways that better reflect our diverse desires. ${ }^{34}$ Yet, she finds this move inadequate, as it does not give sufficient regard to the social element of the ethical moment, as making the world liveable for ourselves is a re-making of the world that affects others. ${ }^{35}$ For this reason Butler wants to expand the dependence we share with the Other beyond a Hegelian notion of recognition. ${ }^{36}$ If we are not sovereign subjects, but rather subjects dispossessed of ourselves because of our social constitution, then the encounter between self and Other takes on a new character and importance. The Other sees us in a way we cannot see ourselves, and we see them in such a manner in turn. Therefore, our encounter with the Other changes both of us, and the recognition we achieve is only momentary. Thus, we are not seeking a resolution of the encounter with the Other but an ethical mode of encounter. This reconsideration of the encounter with the Other, leads Butler to Levinas' idea of infinite and absolute responsibility to the Other. ${ }^{37}$ This responsibility cannot be enumerated or discharged, rather it acts as an always open call to give an account of ourselves, which is in fact dependent upon the Other who sees and hears us in a way we cannot hear or see ourselves. Drawing from Butler, then, we can begin to evaluate rights claims by looking to the kinds of worlds they open up. Her ethical turn prioritises rights claims that make life liveable for those whose existence is precarious. For Butler, by expanding the frame of who counts as human and expressing our desires in a way that is accountable to the Other (including the Other in ourselves) in ongoing relations of dependence, we approach an ethical political creativity. To return to the idea of how we assess performative claims, we can see Butler provides a starting point for evaluating the illocutionary force of a claim by focusing on the desire

\footnotetext{
${ }^{34}$ Ibid., 17-19.

${ }^{35}$ Ibid., 23.

${ }^{36}$ Ibid., 26-30.

${ }^{37}$ Ibid., 30-34.
} 
for liveability, to have space and visibility within the social order. Further, the perlocutionary force of a claim, while still uncertain since it refers to how our claims are received and taken up by others, is mediated by an account of responsibility that exceeds the established boundaries of political membership and conceives of it as an open-ended interrelationship of self and Other.

Despite the important way that Butler's account develops the ethics necessary to a performative politics, there are limitations. First, the ethical quality of our claims is based on the capacity of those claims to act as a medium for recognising and mediating our vulnerability to each other. Even as a rights claim may express new ways of being — demanding the conditions of a liveable life - in Butler's account this is a response to experiences of vulnerability, especially for individuals and groups that are socially marginalised. This vulnerability is ethically important, both in the need to overcome excessive and unequal vulnerability, as well as recognising vulnerability as a condition of social life as such. The priority Butler gives to vulnerability, however, obscures the full range of claims made in practice that we might find laudable. As Honig argues, Butler's focus on vulnerability is itself a kind of universalism, which obscures and displaces other desires and experiences. ${ }^{38}$ The prioritisation of vulnerability lacks objective ethical priority and Butler fails to acknowledge the judgment involved in affirming the centrality of vulnerability.

Butler's interest in the self's relation to the Other, however, suggests further reason to prioritise vulnerability, as the interdependence of self and other exposes both to profound precarity. Yet, this central relationship in the ethical moment is highly abstracted, to the degree that it is difficult to imagine how our responsibility to the Other should play out in practice, especially as the distinction between self and Other seems

\footnotetext{
${ }^{38}$ Honig, Antigone, Interrupted, 30.
} 
to collapse. Further, it presumes an essential relationship that acts as a privileged source of ethical authority, as the Other is granted an absolute value. What emerges is an ethics grounded in our fundamentally precarious and vulnerable condition that holds the individual accountable to the Other. This is an inverted Kantianism, as our condition is not one of rational freedom but determined desire, which leads not to an imperative of respecting the Other as we respect ourselves, but an imperative to take responsibility for that which we cannot determine, both in the Other and ourselves. Unless we reconstruct the normative force of this imperative to take responsibility for the Other, we are left with the same tension found in Kantian moral theory, in which abstract imperatives leave us with either an excessively demanding ethics or one largely compatible with convention. In what follows, I argue that the normative force of such a responsibility should be located in the specific ethical judgments intended to resolves problematic situations.

Zivi and Butler both draw out the important ways rights claims respond to injustice and solicit responses from others. Their accounts, however, require supplementation. Dewey's moral psychology helps us see that performative rights claims originate in a general kind of experience, namely a problematic experience in which the normal habits and customs that guide our actions fail to resolve the problematic experience. Butler's ethical moment is better understood as a distinctive type of problematic experience in which the things we judge to be good are challenged or found wanting. Rights claims express reflective desires to realise specific goods, what Dewey calls ends-inview, which we hope will resolve the problematic experience, enabling us to realise the good we were pursuing or finding a new good to value. 'In being ends of deliberation they are redirecting pivots in action. ${ }^{39}$ For Dewey, there are 'no fixed self-enclosed

\footnotetext{
${ }^{39}$ Dewey, Human Nature and Conduct, 225 (emphasis in the original).
} 
finalities. ${ }^{40}$ The desires that motive our political creativity in ethically problematic moments are cues to a distinctive kind of action, which is aiming to realise not just ends we enjoy or value selfishly but ethical values that make special claims upon us.

It is at this point the second element of responsiveness comes into view, as the judgment that some end-in-view will resolve a problematic experience must be shared when we are concerned with social matters. The audience with which this judgment is shared determines the scope of our ethical obligations. Zivi draws the audience for our claims too narrowly by assuming rights claims address the established democratic community. Butler by contrast, draws it too widely, as an infinite and absolute responsibility to the unknowable Other. Dewey helps us to see rights claims address all those involved in the problematic experience - those trying to alter it, those hoping to preserve it, and those who may inadvertently effect the situation. This general account provides a guide for identifying the audience of our claims in specific contexts. Dewey recognises that the audience of our claim is not the established political community but rather the one we call into being when we identify and seek to resolve a problematic situation. 'A community thus presents an order of energies transmuted into one of meanings which are appreciated and mutually referred by each to every other on the part of those engaged in combined action. ${ }^{\text {'11 }}$ For Dewey, the creation of community 'sets a problem rather than marks a settled achievement. ${ }^{42}$ This focus on rights claims as part of a situationist ethics draws out the centrality of ethical judgement in a performative account of rights, in which the end-in-view we pursue is both shared and involves an affirmation of the consequences of pursuing such ends, generating normative obligations. It is vital, however, to keep the distinctiveness of situated ethical judgments in mind, as they result

\footnotetext{
${ }^{40}$ Ibid., 232.

${ }^{41}$ John Dewey, The Public and Its Problems: An Essay in Political Inquiry (University Park, PA:

Pennsylvania State University Press, 2012), 124.

${ }^{42}$ Ibid., 125.
} 
not in categorical imperatives or regulatory general principles, but situated, contingent and hypothetical imperatives in need of ongoing testing and revision.

\section{Uncertain Judgment and the Problem of Undecidability}

How do we judge the new without subsuming it under an existing rule? This question is central when we are judging the ethical value of new rights-claims. Zerilli brings out what is at stake for performative rights-claims seeking to alter the existing norms of the social order. She addresses this through Arendt's "problem of the new", which Zerilli describes as 'a political question about how we...can affirm freedom as a political reality in a world of objects and events whose causes and effects we can neither control nor predict with certainty. ${ }^{, 43}$ Zerilli argues the preservation of freedom is essential to our evaluations of rights claims, as they not only express our desires for change but also our capacity for free action. Good political creativity must preserve the capacity that makes it possible. Yet, as Zerilli highlights, to 'gain critical purchase on our social arrangement and the ungrounded ground of our form of life... we need to develop a practice of judgment that is not rule-governed. ${ }^{44}$ The challenge here is to find a basis to judge political creativity beyond affirming contingency and openness as ontological conditions in order to distinguish better and worse rights-claiming.

Making a rights claim is an act of judgment. Zerilli helps us understand how we can evaluate these judgments without recourse to an absolute rule. She understands political judgments as acts of creativity, therefore, our claims must be judged in aesthetic rather than epistemological terms, which means that their proper scope is the particular rather than the universal. Following Arendt, Zerilli wants to do away with

\footnotetext{
${ }^{43}$ Zerilli, “'We Feel Our Freedom' Imagination and Judgment in the Thought of Hannah Arendt," 162.

${ }^{44}$ Ibid., 163.
} 
the absolute standards of conventional ethics, abandoning the idea that rights claims are constative utterances that can be true or false. Zerilli argues that when we exercise political judgment our performative acts create specific relations between the individuals sharing in this activity, engaging our public selves to make judgments, which gain validity in proportion to the degree they acknowledge the diversity of perspectives in society and solicit positive responses from those with whom we share political bonds. ${ }^{45}$ These judgments are intended to convince others without recourse to the necessary force of reason. Therefore, political judgment relies on imagination, which becomes a public capacity, as we are not only imagining a different world but also how other people will see our revision to the common world through our attempts to convince them to share it.

Zerilli's account is premised on the impossibility of fully determinate judgments. Therefore, imagination should not aspire to objectivity but rather impartiality, understood as disinterest. This disinterest requires seeing human freedom as an intrinsic good, rather than as being useful to some other end. Validity, then, is tied to the widest possible affirmation of freedom, realised by using one's freedom to imagine a new world from as many perspectives as possible, in an effort to promote the freedom of others. These acts create a shared space for further creativity. In making political judgments we extend concepts beyond their ordinary use into a new context others can accept because they are able to embrace a new framing of objects and events. The force of a rights claim, then, rests in its capacity to serve as a vehicle for imagination. Our evaluations of rights claims are necessarily particular and involve judging the extent to which they have remade the existing situation, moving beyond what is given to something new. This renders political judgment as an existential judgment of both the self

\footnotetext{
45 Ibid., 164.
} 
and common world we try to create. A successful rights claim, then, expresses the pleasure we feel in our shared freedom.

Using Zerilli's analysis we can see the illocutionary force of a performative rights claim in the degree to which it opens up a new world and is a distinctive expression of human freedom. Rights-claims offer new framings of objects, events and subjects. To say "I should have a right to X" affirms the claim and presents it as valuable to others. The perlocutionary force cannot be guaranteed, as it depends upon the uptake of the judgment by others to transform the individual expression of freedom into part of the common world. This reading of rights claims opens up the desires that motivate our claims beyond injury or vulnerability by focusing on the freedom that makes the expression of desires possible, such that good rights-claims are those that express individual freedom in a way that motivates collective political action.

A new problem emerges here, as the ethical quality of our judgments is eclipsed by the aesthetic. The Arendtian understanding of ethics as a set of absolute rules places the ethical in stark opposition to the political as the realm of human freedom and plurality. Zerilli suggests we can evaluate political claims in terms of their aspiration to impartiality, meaning better rights claims are those that reimagine the world for a polity rather than a single individual, but this limits our capacity to evaluate the actual goods pursued in political life. This limitation stems from Zerilli's use of Arendt, who understands modern politics as emerging from the breakdown of traditional beliefs that ground an authoritative account of the good.

There are two important limitations in Arendt's framing. First, Arendt rejects attempts to stabilise and moralise the existing order, but this is not an expression of empathy with those who suffer from the existing order. Rather, as Honig draws out, she rejects attempts to tame uncertainty because they impair the virtuosic display of our 
freedom as individuals taking part in the drama of political life. ${ }^{46}$ This criticism resonates with Dewey's rejection of the traditional separation of intrinsic and instrumental goods because it reflects a class-based division between instrumental practical labour and abstract contemplation of ideal values. ${ }^{47}$ While Arendt revises this classical dichotomy, she steadfastly maintains a hierarchical separation marking out higher intrinsic and lower instrumental ends. ${ }^{48}$ Second, while authority may no longer be found in traditional ethics, it remains of central importance to Arendt, as she valorises our capacity to make promises as a collective act of political commitment, which provides politics with a modern form of authority. ${ }^{49}$ A promise is an heroic gesture made in the face of uncertainty, which not only demands much of us as political actors-more than many may have — but also privileges bravery and boldness while giving little thought to the conditions that make such virtues possible or the resources needed to face uncertainty. In doing so, an Arendtian-inspired account of performative rights ignores the political import of more everyday experience and the ethical importance of instrumental goods.

The political heroism Arendt celebrates draws a divide between free acts of selfcreation and instrumental actions, with the former expressing a new and higher life of the public realm in which we transcend the necessary and determined in favour of what we freely make of ourselves. ${ }^{50} \mathrm{We}$ are left with a practice of judgment that rests on a worrying account of politics, one which seems to take us away from a concern with how rights might better the lives of those marginalised and oppressed in the existing order, and towards a politics privileging the courageous and bold. I do not want to suggest that Arendt's politics are Zerilli's but there are limitations to the Arendtian

\footnotetext{
${ }^{46}$ Honig, Political Theory and the Displacement of Politics (Ithaca, NY: Cornell University Press, 1993), 75.

${ }^{47}$ Dewey, Human Nature and Conduct, 185-8.

${ }^{48}$ Hannah Arendt, The Human Condition (Chicago, IL: University of Chicago Press, 1998).

${ }^{49}$ Honig, Political Theory and Displacement of Politics, 77.

${ }^{50}$ Ibid., 81.
} 
framing, as her rejection of the ethical as an external absolute that limits our freedom leads her to favour an ethos of political heroism in defence of the unique value of freedom. ${ }^{51}$ In marked contrast, Dewey's understanding of the instrumental nature of ethical judgment reconnects performative rights claiming to an everyday concern with improving lived experience. The validity of rights-claims, intended to address problematic situations, must rest in some measure in their ability to actually change the situation at hand, linking 'the necessarily relatively inadequate valuation of the act which takes place before the act' to 'the complete evaluation of judgment of it which is possible afterwards. ${ }^{52}$ This move reaffirms the connection between a performative-account of rights and an activist democratic politics.

Arendt's use of promising as a standard of judgment is also problematic, as she is relentlessly sceptical of external standards but maintains there is a need for a stable vantage point to reflect on our action. ${ }^{53}$ Promising is the source of modern authority as it is the commitment of the community to the maintenance of public life. Arendt reads the political promise or declaration as a performative speech act devoid of constative content, of any appeal to an external standard for meaning or authority. ${ }^{54}$ It is this distinction between constative and performative in Arendt that Honig criticises, drawing on Jacque Derrida's analysis of J.L. Austin. According to Derrida, Austin undermines the uncertainty of performative statements by insisting that they take place within a context of meaning that gives them greater surety. He argues that Austin obscures the ambiguity of contextual meaning, which is unsettled by the imperfection of reiteration in practice. ${ }^{55}$ This prevents Austin from acknowledging the difficulty of separating the

\footnotetext{
${ }^{51}$ Ibid., 78-9.

52 John Dewey, Lectures on Ethics, 1900-1901, ed. Donald F. Koch (Carbondale, IL: Southern Illinois University Press, 2003), 219.

${ }^{53}$ Honig, Political Theory and Displacement of Politics, 84-5.

${ }^{54}$ Ibid., 103.

55 Ibid., 90.
} 
performative from the constative given the ambiguity of social meanings. Honig embraces Derrida's notion of undecidability to criticise Arendt's privileging of the purely performative promise untouched by an external absolute. Arendtian promising either secures limited certainty by placing the act of promising within a practice of promisemaking that constrains our freedom, which undermines the acts vaunted uncertainty; or if it is not ritualised, it is unclear how promises would provide any certainty at all, which undermines its role as a way of coping with uncertainty. ${ }^{56}$ Honig, however, does not suggest this is simple incoherence, but rather that promises are inherently ambiguous and undecidability intrinsic to speech acts. The promise is not only an act of freedom, a pure performative, it is also a constative act, an appeal to some external standard. ${ }^{57}$ While Arendt is committed to a politics that privileges the always ongoing amendment of political life, she sees politics as taking place in a separate and higher realm secured through the ambiguous act of promising. Honig instead embraces the inseparability of the performative and the constative; she begins from undecidability. ${ }^{58}$

Arendt's pure political performative remains haunted by an ethical constative. The challenge for Honig, then, is how we might negotiate this undecidability. It leads her in an existential direction, as she argues for the necessity of a democratic ethos that guides our rights claims. This ethos is a cultivated way of responding to the always potential closure of the political by the ethical, a commitment to resist closure. This commitment is a kind of absolute, but one that Honig thinks is responsive to the imposition of the ethical. She describes this as an agonistic humanism, which holds contradictory commitments at the same time. ${ }^{59}$ On one hand she refuses the closure of the

\footnotetext{
${ }^{56}$ Ibid., 88.

${ }^{57}$ Ibid., 107.

58 Ibid., 115.

${ }^{59}$ Honig, Antigone Interrupted, 193.
} 
political by any external absolute standard, while on the other she is committed to the virtues of democratic activism.

Rights claims, for Honig, rework the existing political order and remake privileged identities, and as such they are part of the process of democratic politics. Yet, she takes this further by focusing on how rights-claims remake our individual and collective identities in a way not fully accounted for in the normal democratic process. ${ }^{60}$ She sees rights-claims as keeping open the moment of democratic founding, in which the basic terms of political life and the identity of the community are renegotiated. She frames the practice of rights claiming as an 'expressive sovereignty', which opposes and in fact remakes institutional sovereignty. ${ }^{61}$ Rights-claims are expressions of power, which can be used to subvert the existing order. This power must be acknowledged as potentially dangerous, even as we try to ensure that rights claiming is good not just for the claimant but for everyone. Honig renders rights claiming as a form of democratic activism guided by two virtues: agonistic respect and critical responsiveness. ${ }^{62}$ Agonistic respect demands we see those holding different commitments as equally entitled to those commitments and to engage in political contestation. Critical responsiveness in turn asks those occupying positions of privilege to be open to hearing alternative claims and recognising the way in which their commitments may in fact harm others.

To return to the idea of evaluating performative rights-claims in terms of their illocutionary and perlocutionary force, we see Honig understands performative rights in terms of a claim's illocutionary force to re-stage the foundational democratic moment, opening up fundamental questions about the political order and the membership

\footnotetext{
${ }^{60}$ Bonnie Honig, Democracy and the Foreigner (Princeton, NJ: Princeton University Press, 2003); Honig, Antigone Interrupted.

${ }^{61}$ William E. Connolly, Pluralism (Durham, NC: Duke University Press, 2005), 145.

${ }^{62}$ Bonnie Honig, "The Time of Rights: Emergent Thought in an Emergency Setting: The Paradox of Politics," in The New Pluralism: William Connolly and the Contemporary Global Condition, ed. David Campbell and Morton Schoolman (Durham, NC: Duke University Press, 2008), 85-120.
} 
of the community. Its perlocutionary force, its uptake, is shaped by the virtues of agonistic respect and critical responsiveness. Further, she recognises the performative quality of our rights-claims is haunted by their constative quality. This means that when we make a new demand and exercise expressive sovereignty, we are also articulating an absolute. Honig insists that we recognise this undecidability, while guarding against the imposition of the ethical.

Zerilli and Honig both wrestle with how we judge without absolutes. In Zerilli's account, judgment is rendered as a creative political act evaluated in terms of its impartiality and expression of human freedom. Yet, the ethical aspect of judgment in her account is reduced to the question of whether our actions preserve freedom, such that the ethical is subsumed in the political. This can be seen in the Arendtian valorisation of self-expression in the public sphere, as not only is the value of self-expression taken for granted, but the ways in which such a valorisation excludes and marginalises those who value different goods, or lack the capacity of public self-expression, is not considered. Honig resists this eclipse of the ethical by focusing on the inseparability of the performative and constative, but only to a degree. Honig's existentialism is limiting, as the commitment to democracy, and in particular the democratic moment of founding, is presented simply as a disposition. While many of our values surely are inherited dispositions, such an understanding of the values we pursue in political action leaves little room for the use of intelligence to improve our judgments of the good and to render them in terms that enable the creation of common values. Where Honig is mistaken, I believe, is her worry that the affirmation of a good is always a contingent preference masquerading as an absolute value. Dewey provides another way of understanding the nature and function of ethical judgment, one which provides a better way of understanding and evaluating performative rights claims. 'Morals is not a catalogue of acts 
nor a set of rules to be applied like drugstore prescriptions of cook-book recipes. ${ }^{93}$ The framing of ethical matters in terms of the general and universal has divorced judgment 'from those interests of daily life which because of their constancy and urgency form the preoccupation of the great mass. ${ }^{64}$ By rejecting the absolutist framing of conventional ethics as an intellectual error that blunts our intelligence in addressing human problems and tends to serve the interests of the powerful, Dewey suggests the quotidian struggle for justice is the true form of ethical action, which should be served by philosophical reflection aimed at "contributing in however humble a way to methods that will assist us in discovering the causes of humanity's ills. ${ }^{65}$

\section{A Situationist Ethics of Performative Rights Claims}

Drawing on Dewey's ethics, I suggest we think of ethics less in terms of rules, laws, and imperatives, ${ }^{66}$ and instead understand ethical judgments in terms of the situational goods we value, which become the ends to which we provisionally commit ourselves. As Dewey says, there is 'no "The Good", but an aggregate of fragmentary ends. ${ }^{67}$ This approach shares much with the performative accounts examined thus far: it locates ethical inquiry and action in specific moments of uncertainty, assess our action in terms of a broad ethos rather than in relation to universal rules, and denies the abstract priority over the particular. It adds a more detailed account of the ethical moment, and its importance to rights claims, as well as providing a clearer account of ethical judgment. By focusing on specific situations and the necessity of experimental action, a Deweyan

\footnotetext{
${ }^{63}$ Dewey, Reconstruction in Philosophy, 97.

${ }^{64}$ Ibid., 98.

${ }^{65}$ Ibid., 102.

${ }^{66}$ Dewey, Human Nature and Conduct, 283.

${ }^{67}$ John Dewey, Outlines of a Critical Theory of Ethics (New York, NY: Hilary House, 1957), 119.
} 
ethics forgoes certainty and constraint in favour of the cultivation of a critical intelligence that develops our capacities to act ethically.

Ethical questions arise in context. For Dewey, the ethical moment is not only initiated by a special desire or experience — hurt, vulnerability, or the desire to express our freedom — rather it arises from the quotidian experience of disruption. ${ }^{68}$ Problematic situations arise when our everyday experience ceases to run smoothly, when our habitual and customary ways of acting fail us. This account certainly includes profound experiences of political injustice or social vulnerability, but the importance of those experiences does not mark out a difference in the type of experience. In a problematic situation, the ends we normally pursue and the goods we normally value are hindered and blocked. The expected context of our activity has broken down-our constative statements may not mean what we think they mean and our performative statements may not have the effect we expect. In contrast to Butler, this ethical moment does not reveal an alien social world pressing in upon us, but rather a complex social context in which most action is necessarily habitual and customary, but where a specific aspect of that experience has ceased to function. Disruption, and the desire to address it, should not lead us to look for an absolute rule. The solution to a problematic situation lies in its specificity and the concrete action needed to resolve it. Further, Dewey's account gives added importance to Honig's virtue of critical responsiveness, as individuals who are privileged within the existing order are likely to find fewer and less disruptive problematic situations, while those who are disadvantaged, exploited, and marginalised are able to see the dysfunction and destructive aspects of the social order with greater clarity. This adds to the importance of responsiveness, as it is about more than concern for those who suffer, it is an affirmation that those that suffer know important things about

\footnotetext{
${ }^{68}$ Dewey, Human Nature and Conduct, 125-30, 169-71, and 189-98.
} 
our common lives. Those with privilege should be empathetic, but they should also be responsible for their own ignorance, giving the virtue of critical responsiveness greater urgency.

Distinctly ethical problems arise when the goods we pursue are compromised, perhaps because social conditions block the realisation of these goods, or maybe the goods pursued have harmful consequences we failed to foresee. Whatever the specific problem we encounter, the solution is not found in abstract reflection or practical action alone. Rather, resolving a problematic situation requires bringing these activities together. The ethical moment requires a reconstruction both of the ideals we pursue and our ways of acting, thus ethical judgment begins with a diagnosis of the reasons specific goods are in question, which is a social process that takes account of how the goods we pursue shape us, the way they are enabled or hindered through social conditions, and their impact on others. This approach gives more space for reasoned deliberation in controversial matters, as the focus is on concrete and specific harms - and it offers no promises of an escape from disagreement and conflict, only a hope that we can do more to avoid the excesses of the political.

$[\mathrm{T}]$ he transfer of the burden of the moral life from following rules or pursuing fixed ends over to the detection of the ills that need remedy in special cases and the formation of plans and methods for dealing with them, eliminates the causes which kept moral theory controversial, and which have also kept it remote form helpful contact with the exigencies of practice. The theory of fixed ends inevitably leads thought into the bog of disputes that cannot be settled. ${ }^{69}$

\footnotetext{
${ }^{69}$ John Dewey, Reconstruction in Philosophy, 95.
} 
This reflection leads to a new process of valuation. Dewey draws a vital distinction between valuing and valuation. The fact that we enjoy a good will give us reason to value it, but this is an unreflective valuing that does not consider the consequences and meaning of treating a particular good as an end worth committing ourselves to-valuation is the name Dewey gives to this consideration of the consequences of our valuing. 'If I satisfy this desire just as it is, what other tendencies of my nature shall I be strengthening which I really do not want to strengthen? And what satisfactions shall I be preventing or hindering whose satisfaction I really wish?'70 The initial ethical judgment, however, is only hypothetical, as its fuller meaning and consequences can only be found in action.

Hypothetical ethical judgments are tested through action in the world. The end we pursue after our considered evaluation of various goods is not an ideal to be affirmed in the abstract, but a living guide to creative action in concrete situations. Dewey advocates the use of imaginative rehearsals in which we try to picture the consequences of acting upon the goods we judge worthy of our commitment, but these can only prepare us for the actual test of pursuing reconstructed ends through practical action that gives life to the new worlds we imagine. ${ }^{71}$ Where our attempts to reconstruct experience are successful, a new end is consummated in action and it is here we find the only absolute value of an ethical judgment. ${ }^{72}$ Its domain, however, is limited to that specific experience. We can say of the successfully reconstructed end that it is the good or right thing to do in that moment only. Dewey is insistent that when we make particular ends regulative across experiences, we must recognise that these ends are only rough guides to

\footnotetext{
${ }^{70}$ John Dewey, Lectures on Ethics, 1900-1901, 194.

${ }^{71}$ Steven Fesmire, John Dewey and Moral Imagination: Pragmatism in Ethics (Indianapolis, IN: Indiana University Press, 2003), 69-91.

72 John Dewey, Experience and Nature (Chicago and London: Open Court Publishing Company, $1925), 78-83$ and $116-18$.
} 
future action, not legislative absolutes. ${ }^{73}$ The judgements we carry over from past experience are dead judgements, tools that may help us navigate the world but not final valuations that determine our new experiences. The ethical moment always returns.

Performative accounts of rights have tended to privilege the question of how we realise the goods we affirm, rather than how we make our valuations, which reflects a suspicion of the ethical. If ethical judgment is understood as part of the everyday and shared work of valuation then it can be brought back together with the work of affirmation and action, allowing the ethical and political to be related in a more robust manner. We can judge a rights-claim as a constative statement, measuring it against the law or existing custom, but this does not answer the lived ethical question. We must consider its illocutionary and perlocutionary force, in Dewey's terms we consider how far our rights claims resolve the problems that inspire them, through creative and collaborative action. This is more than a crude instrumentalism, as a resolution of a problematic situation requires us to evaluate how the new good we pursue in turn remakes our experience, in terms of what it enables us to do and what it contributes to our character.

Applying these ideas to a performative account of rights, I argue rights-claims, which seek to remake political life, are best inspired by responsiveness understood as a commitment to extending care for ourselves and others, a 'cherishing attention to that in whose potentialities we are interested' as part of an ethical response to a 'present having a future which is ambiguous. ${ }^{74}$ This care is expressed by efforts to increase the capacity of each of us to share in making the world cooperatively and accepting our responsibility to those we live with in community. These general ideals will not give us a determinate set of rights but rather a perspective from which to consider the more

\footnotetext{
${ }^{73}$ John Dewey, Quest for Certainty (New York, NY: J. J. Little and Ives Company, 1929), 264-5.

${ }^{74}$ Ibid., 215.
} 
specific goods we seek to pursue through political action. Further, it pushes our concern for others beyond responsibility toward a focus on how our actions, both individual and collective, empower others to participate in social life. Finally, a situationist ethics highlights the importance of the consequences of performative claims for our evaluation of them. This is not simply a question of what a particular action may do, but of what the goods we commit ourselves to make of us, as individuals and communities, namely how far they make us more democratic.

The idea of a democratic ethos returns; rendered in Deweyan terms a democratic ethos expresses a concern for how our common world is made, which requires sustained critical consideration of our existential commitments. There is, however, an important ambiguity to address in a situationist ethics: the democratic ethos by which we judge the outcomes of our actions and the quality of our character seems itself an absolute. Dewey speaks of growth as an overarching value that justifies our commitment to democracy, but this is problematic. Growth should not be understood as an absolute standard, which would undermine the idea of a situationist ethics centred on experimental action. Dewey's idea of growth is similar to Honig's privileging of the democratic moment, it provides us with a general orientation. If ethics is the application of critical intelligence to questions of value, then growth provides a guiding principle that is necessarily corrigible. Growth in the context of ethical intelligence suggests that we should value actions and goods that increase the control we have over our own lives and encourage the development of personality for all, by which Dewey means empowering individuals to develop their capacities in order to find fulfilment and contribute to social life. ${ }^{75}$ This ties Dewey's ethics to his understanding of democracy as a 'way of life

\footnotetext{
${ }^{75}$ Dewey, Outlines of a Critical Theory of Ethics, 188-90.
} 
guided by a working faith in the possibilities of human nature'. ${ }^{76}$ Democracy is more than a particular political arrangement, it is a general commitment to enable everyone to contribute to social life. This commitment to democracy only finds its value in its capacity to continue serving the resolution of the problems of lived experience.

The purpose of ethics, then, is not to limit freedom but to reflect upon and improve our actions in service of better political creativity. To be ethical is a matter of craft rather than genius, a matter of making practice more intelligent rather than authoritative. A situationist ethics is the process of learning to make better habits, to reflect on how to build a more democratic character open to otherness, built through participatory social relationships, and committed to change and contestation rather than consistency and certainty. The act of commitment central to a performative account of rights does not disappear, but it is rendered less heroic, less individualistic. We commit to building a democratic character for the value it has in realising the freedom of all in community, through the development of creative critical intelligence.

\footnotetext{
${ }^{76}$ John Dewey, John Dewey and the Promise of America, Progressive Education Booklet 14 (Columbus, OH: American Education Press, 1939), 14.
} 


\section{References}

Arendt, Hannah. 1998. The Human Condition. Chicago, IL: University of Chicago Press.

Arendt, Hannah. 1994. "Some Questions of Moral Philosophy," Social Research, 61, no. 4: 739-64.

Brown, Wendy. 1995. States of Injury: Power and Freedom in Late Modernity. Princeton, NJ: Princeton University Press.

Butler, Judith. 2009. Frames of War: When Is Life Grievable? London and New York: Verso.

Butler, Judith. 2005. Giving an Account of Oneself. New York, NY: Fordham University Press.

Butler, Judith. 2004. Undoing Gender. New York \& London: Routledge.

Connolly, William E. 2005. Pluralism. Durham, NC: Duke University Press.

Dewey, John. 2012. The Public and Its Problems: An Essay in Political Inquiry. University Park, PA: Pennsylvania State University Press.

Dewey, John. 2004. Reconstruction in Philosophy. (Mineola, NY: Dover Publications.

Dewey, John. 2003. Lectures on Ethics, 1900-1901. Edited by Donald F. Koch. Carbondale, IL: Southern Illinois University Press.

Dewey, John. 2002. Human Nature and Conduct: An Introduction to Social Psychology. Amherst, NY: Prometheus Books.

Dewey, John. 1957. Outlines of a Critical Theory of Ethics. New York, NY: Hilary House.

Dewey, John. 1939. John Dewey and the Promise of America. Progressive Education Booklet 14. Columbus, OH: American Education Press.

Dewey, John. 1929. Quest for Certainty. New York, NY: J. J. Little and Ives Company.

Dewey, John. 1925. Experience and Nature. Chicago and London: Open Court Publishing Company.

Fesmire, Steven. 2003. John Dewey and Moral Imagination: Pragmatism in Ethics (Indianapolis, IN: Indiana University Press.

Hoover, Joe. 2016. Reconstructing Human Rights: A Pragmatist and Pluralist Inquiry into Global Ethics. Oxford: Oxford University Press.

Honig, Bonnie. 2013. Antigone, Interrupted. Cambridge, Cambridge University Press.

Honig, Bonnie. 2009. Emergency Politics: Paradox, Law, Democracy. Princeton, NJ: Princeton University Press.

Honig, Bonnie. 2008. "The Time of Rights: Emergent Thought in an Emergency Setting: The Paradox of Politics," in The New Pluralism: William Connolly and the Contemporary Global Condition. Edited by David Campbell and Morton Schoolman. Durham, NC: Duke University Press, pp. 85-120.

Honig, Bonnie. 2003. Democracy and the Foreigner. Princeton, NJ: Princeton University Press.

Honig, Bonnie. 1993. Political Theory and the Displacement of Politics. Ithaca, NY: Cornell University Press.

Isin, Engin. 2016. "Enacting International Citizenship," in International Political Sociology: Transversal Lines. Edited by Tugba Basaran et al. London and New York: Routledge, pp. 185-204.

Zerilli, Linda M. G. 2012. "Value Pluralism and the Problem of Judgment Farewell to Public Reason," Political Theory, 40, no. 1: 6-31. 
Zerilli, Linda M. G. 2005. “We Feel Our Freedom' Imagination and Judgment in the Thought of Hannah Arendt," Political Theory, 33, no. 2: 158-88.

Zivi, Karen. 2012. Making Rights Claims: A Practice of Democratic Citizenship. Oxford: Oxford University Press, 2012.

Zivi, Karen. 2008. "Rights and the Politics of Performativity," in Judith Butler's Precarious Politics: Critical Encounters. Edited by Terrell Carver and Samuel A. Chambers. London and New York: Routledge, pp. 157-69. 